\title{
French supplies law threatens research
}

[PARIS] French researchers are warning that last summer's efforts by the Ministry of Economy and Finance to tighten up the implementation of a law on the ordering of equipment and materials by public institutions risks bringing public research in the country to a halt.

Already the laboratories of the Centre National de la Recherche Scientifique (CNRS) have been prevented from paying some of their suppliers. Laboratories belonging to other public research agencies will soon find themselves in the same situation.

The law requires every public institution in France to seek bids for national orders worth more than FF300,000 (US\$53,000). Companies submitting the winning bid would become the sole source of supply to that institution for the length of the contract, which will be at least one year.

Until now, public research organizations have been able to use an annual exemption from these requirements to give them time to modify their purchasing policies.

Some progress has already been achieved in this direction, as the CNRS has reduced the number of suppliers for certain products from 65 to three or four. But the Ministry of Economy and Finance feels there should be only one supplier. The issue has become even more sensitive since a recent reform increased the penalties for preferential treat- ment of contractors, including those covered by the law on public purchasing.

CNRS officials say research institutions have not been able to adapt to the law on public purchasing because they cannot predict their needs on a long-term basis. Hélène Richard-Foy, director of research at CNRS's Laboratory of Eukaryote Molecular Biology in Toulouse, says the law is incompatible with the way research is carried out: "For antibodies, for example, it is impossible to rely on a single supplier as antibodies recognizing the same protein but coming from different sources will not have the same reactivity or effectiveness according to the experimental approach being used."

François Coulier, a researcher at the biomedical research agency INSERM, says: "How can we react immediately to the appearance of a new reactive agent produced by suppliers who have been eliminated by the purchasing strategy?" He points out that "the 400 small high-technology companies that Claude Allègre [the research minister] wants to see created will have no chance of becoming suppliers to public research institutions".

The current arrangements end at the end of December, but CNRS officials say the normal procedure for seeking bids for supply contracts takes between six and eight months.

Last month, several researchers at
INSERM's Institute of Cancer and Immunology in Marseilles sent a letter to Allègre with a petition signed by more than 1,300 scientists. They asked Allègre to approach the finance minister, Dominique Strauss-Kahn, to try to resolve the situation. Allègre replied that he had been trying to do this for several months. "My attempts have not yet achieved results, but a positive outcome remains possible," he said. Nothing has been heard from Allègre since then, so it now seems to be up to the prime minister, Lionel Jospin, to resolve the issue.

CNRS officials have already run up bills with suppliers with which they do not have contracts. But the agency's financial controller, who reports direct to the finance ministry, has been refusing to honour these commitments, resulting in an impasse.

These steps by CNRS seem to have precipitated government action. According to an official in Jospin's office, a new text addressing the situation is being checked by lawyers before being submitted this week to the state council for approval.

The official says the text confirms the research institutes' exemption, and so is unlikely to please the finance minister. It would give laboratories flexibility in purchasing policies, and has been drafted in a way that is compatible with planned reforms in public purchasing policy.

Eric Glover

\section{Human genome declaration looks set for United Nations approval}

[PARIS] The Universal Declaration on the Human Genome and Human Rights, adopted last year by the United Nations Educational, Scientific and Cultural Organization (Unesco), is set to be adopted by the United Nations itself at its fifty-third general assembly on 10 December.

Supporters of the initiative hope it will give greater political prominence to the human rights issues that, they say, are raised by advances in genetics.

This week the new government of Germany said it would support the text. Germany was the only country to have opposed adoption of the text in last year's vote at Unesco, and as late as last week, at a meeting of the UN commission on human rights, said it had not yet decided on whether to endorse the text.

The approval of the text by the commission, combined with German support, means that it now seems certain to be adopted at the general assembly — which coincides with the fiftieth anniversary of the UN's Universal Declaration of Human Rights. The text is to be presented as a 'procedural resolution', which means that its approval will not require a vote but simply

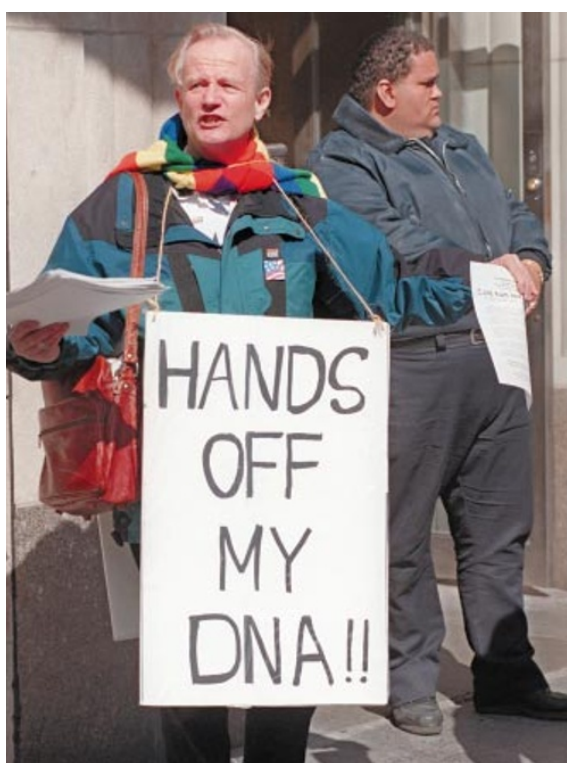

Lobbying pays off: UN declaration will include condemnation of human cloning for reproduction.

an 'endorsement' of the existing Unesco text.

The declaration, which has been strongly promoted by France, has already attracted 30 sponsors, including Japan, India and
Canada. Dozens of other countries, including the United States and United Kingdom, will support the resolution.

The declaration commits signatories to opposing genetic reductionism and its consequences. It endorses the principle of scientific freedom, although stipulating that this should never be given priority over human rights.

But it avoids specific provisions on medical practices, on the grounds that translating broad principles into legislation is best left to individual states, acting in the light of their own traditions - although Unesco bowed to pressure last year and added a condemnation of human cloning for reproductive purposes and germ-line gene therapy (see Nature 388,$508 ; 1997$ ).

The text will be non-binding on member states. But, like existing UN declarations, it will provide grounds for groups or individuals claiming to have been discriminated against to challenge laws or practices that are contrary its provisions. It also provides a benchmark for countries planning to draft bioethics legislation such as Japan and many developing countries.

Declan Butler 